\title{
Characteristics and clinical trial results of agonistic anti-CD40 antibodies in the treatment of malignancies (Review)
}

\author{
DA-KE LI and WEN WANG \\ Department of Clinical Science, Shanghai R\&D Center, State Key Laboratory of Translational Medicine and \\ Innovative Drug Development, Jiangsu Simcere Pharmaceutical Co. Ltd., Shanghai 201318, P.R. China
}

Received December 26, 2019; Accepted May 19, 2020

DOI: $10.3892 / \mathrm{ol} .2020 .12037$

\begin{abstract}
Cluster of differentiation 40 (CD40) mediates many immune activities. Preclinical studies have shown that activation of CD40 can evoke massive antineoplastic effects in several tumour models in vivo, providing a rationale for using CD40 agonists in cancer immunotherapy. To date, several potential agonistic antibodies that target CD40 have been investigated in clinical trials. Early clinical trials have shown that the adverse events associated with agonists of CD40 thus far have been largely transient and clinically controllable, including storms of cytokine release, hepatotoxicity and thromboembolic events. An antitumour effect of targeting CD40 for monotherapy or combination therapy has been observed in some tumours. However, these antitumour effects have been moderate. The present review aimed to provide updated details of the clinical results of these agonists, and offer information to further investigate the strategies of combining CD40 activation with chemotherapy, radiotherapy, targeted therapy and immunomodulators. Furthermore, biomarkers should be identified for monitoring and predicting responses and informing resistance mechanisms.
\end{abstract}

\section{Contents}

1. Introduction

2. The structure of CD40/CD40L

3. The physiological role of CD40/CD40L

4. The role of the CD40/CD40L pathway in malignancy

5. The profiles of agonistic antibodies targeting CD40 for cancer therapy

Correspondence to: Dr Wen Wang, Department of Clinical Science, Shanghai R\&D Center, State Key Laboratory of Translational Medicine and Innovative Drug Development, Jiangsu Simcere Pharmaceutical Co. Ltd., 118 Furonghua Road, Shanghai 201318, P.R. China

E-mail: ortho123@hotmail.com

Key words: agonist, anti-CD40, antibody, tumour, clinical trial
6. Clinical trials of anti-CD40 mAbs for treating the malignancies

7. Other agonistic CD40 antibodies

8. Safety and clinical tolerability of anti-CD40 agonistic antibodies

9. Conclusion and outlook

\section{Introduction}

Cluster of differentiation 40 (CD40), which belongs to the tumour necrosis factor (TNF)/TNF receptor (TNFR) family, is a 277-amino acid, 45-50 $\mathrm{kDa}$ transmembrane glycoprotein $(1,2)$. Under physiological conditions, CD40 is primarily expressed on the membranes of various antigen-presenting cells (APCs), including dendritic cells (DCs), B-cells and monocyte-macrophages (3). It can also be expressed on nonimmune cells, including endothelial cells, epithelial cells, haematopoietic progenitors, and platelets $(4,5)$ as well as tumour cells $(6,7)$.

The natural ligand of CD40 (CD40L, otherwise known as CD154, TRAP or T-BAM), which also belongs to the TNF/TNFR family, is a 34-39 kDa type II integral membrane protein that is primarily expressed by active $\mathrm{CD} 4^{+} \mathrm{T}$ helper cells under inflammatory conditions. Previous studies have shown that the soluble form of CD40L, which lacks the transmembrane region, possesses biological activities similar to the transmembrane form $(8,9)$.

The interaction between CD40 and CD40L is critical for the generation of a series of systemic immunizing inflammatory reactions. This includes the class switching and affinity maturation of immunoglobulins; secretion of cytokines; the survival, proliferation, differentiation and adhesion of $B$ cells; and the development of memory B cell generation and germinal centres (10). In addition, CD40 intracellular signalling induces the apoptosis of many transformed cells both in vitro and in vivo, such as breast cancer and haematological malignancy cells $(6,7)$.

With the inspiring successes of monoclonal antibodies (mAbs) targeting programmed cell death protein (PD-1)/programmed cell death ligand (PD-L1) in cancer therapy, immunomodulation by antibodies has been regarded as an attractive way of boosting anticancer responses (11), CD40 is an emerging immunotherapy target that plays a critical 
role in human immunity. Extensive preclinical research has proven that CD40 ligation stimulates antitumour immunity via several potential mechanisms across various lymphoid $(12,13)$ and solid tumours (14-16).

To date, several anti-CD40 mAbs have been investigated by clinical studies. Here, we present an overview of the physiological and immunological context of CD40/CD40L, emphasizing the clinical outcomes of anti-CD40 mAbs for treating malignant disease.

\section{The structure of CD40/CD40L}

The human CD40 gene is located on chromosome 20q11-13 and encodes a polypeptide chain of 277 amino acids, including an extracellular region of 193 amino acid residues, a transmembrane region of 22 amino acid residues and an intracytoplasmic region of 62 amino acid residues (17). As CD40 lacks intrinsic kinase activity in the cytoplasmic tail, the signal is mainly transferred by recruitment of TNF R-associated factors (TRAFs), which are cytoplasmic adapter molecules (18). TRAF trimers specifically recruit tyrosine and serine/threonine kinases to initiate rapid protein phosphorylation, which activates downstream signal transduction pathways, including the phosphoinositide 3-kinase (PI3K), p38/mitogen-activated protein kinase (38 MAPK), nuclear factor- $\kappa \mathrm{B}(\mathrm{NF}-\kappa \mathrm{B})$ and c-Jun-NH2-kinase (JNK)/stress-activated protein kinase pathways (19-22).

The human CD4OL gene is located on the $\mathrm{X}$ chromosome, Xq26.3-Xq27.1, and has five exons that span $12-13 \mathrm{~kb}$, its DNA consists of a 783 bp reading frame encoding 261 amino acids, including an intracytoplasmic region of 22 amino acid residues, an extracellular region of 215 amino acid residues and a transmembrane region of 24 amino acid residues, which has a signalling and anchoring function $(23,24)$. The CD40 ligand amino acid sequence has homology to the amino acid sequences of the extracellular regions of other TNF gene family members, such as TNF- $\alpha$ and tissue growth factor- $\beta$. CD40L has a carboxyl terminus located extracellularly and is a type II membrane protein that lacks an amino-terminal signal peptide. There are two soluble forms of CD40L (31 and $18 \mathrm{kDa}$ ), which retain the ability to bind CD40 and elicit signals in the form of homotrimers (25).

\section{The physiological role of CD40/CD40L}

Unlike other TNFR costimulatory targets, CD40 is mainly expressed on APCs including B-cells, macrophages and monocytes (3). In addition, the CD40 is also present on non-immune cells, such as endothelial cells, epithelial cells, hematopoietic progenitor cells and platelets as well as various tumour cells, including malignant lymphoma cells, leukaemia cells and solid tumour cells (4-7).

The key physiological function of the CD40/CD40L pathway is mediated by CD40 ligation on APCs, especially dendritic cells (DCs). CD40L binding with CD40 leads to the activation of DCs, including improving their antigen presentation ability by upregulating the expression of other costimulatory molecules [major histocompatibility complex (MHC) class II, CD58, CD80/86 and CD70] and downregulating the expression of immunosuppressive molecules such as PD-L1 (19-21). It also develops a pro-survival signal and increases the release of various cytokines, including interleukin (IL)-1 $\beta$, IL-6, IL-8, IL-12, TNF- $\alpha$ and interferon (IFN)- $\gamma$ by DCs (26-28), and hence further enhances the cytotoxic response and prevents immune tolerance induction.

The binding of CD40L to CD40 also activates macrophages to directly kill tumour cells (29) and leads to the secretion of IL-1 $\beta$, IL-6, IL-8, IL-12, TNF- $\alpha$, IFN- $\gamma$ and nitric oxide (27). These cytokines mediate the pro-inflammatory response and are crucial to macrophage cross-priming and cytotoxic function $(30,31)$.

The ligation of CD40 activates resting B lymphocytes and causes these cells to differentiate into secretory plasmocytes or memory B lymphocytes but inhibits the growth and immunoglobulin production of active B lymphocytes (32). The differentiation path of activated B lymphocytes is partly dependent on the extent of CD40 activation. Short-term CD40L exposure can differentiate B cells into plasma cell lymphocytes, while long-term CD40L exposure can produce CD $40^{+}$memory B lymphocytes (33). A previous study found that CD40-stimulated B lymphocytes prolong the lifespan of memory B lymphocytes in vivo (34). In addition, patients with $\mathrm{X}$-linked hyper-IgM immunodeficiency syndrome, which is caused by CD154 mutation/dysfunction, are unable to perform immunoglobulin class switching (35).

\section{The role of the CD40/CD40L pathway in malignancy}

CD40 is expressed on $\sim 100 \%$ of malignant B cell tumours (such as Hodgkin's lymphoma, non-Hodgkin's lymphoma, Burkitt lymphoma and multiple myeloma) (36). CD40 can also be identified on the cell surface of $70 \%$ of malignant epithelial tumours (including breast cancer, nasopharyngeal cancer and rectal cancer) (36).

There are diverse roles of CD40 pathway activation in cancer $(12,37)$. Activation of the CD40 pathway has been proven to enhance the host antitumour immune response and/or directly induce tumour cell apoptosis in several models, especially in primary high-grade B cell lymphoma models of Burkitt's lymphoma, diffuse large B cell lymphoma (DLBCL) or Epstein-Barr virus-driven lymphoma $(12,38)$. This pro-apoptotic effect of CD40 ligation is associated with the activation of cytotoxic ligands of the TNF superfamily (39). However, in some low-grade B cell malignancies, such as follicular lymphoma, chronic lymphocytic leukaemia and hairy cell leukaemia, stimulation of CD40 promotes malignant transformation, tumour proliferation, lymphomagenesis and resistance to chemotherapy (39-43) by inducing overexpression of survival proteins, such as Bcl-x and Bfl-1/A1, and downregulation of FLICE-inhibitory protein $(44,45)$. Collectively, these studies have highlighted that activation of the CD40 pathway can exert either apoptotic or pro-survival effects depending on the type and differentiation state of the cancer cells involved (10). Therefore, care should be taken in clinical trials to exclude tumours for which preclinical trials have shown that activation of the CD40 pathway can lead to tumour progression.

Both preclinical experimental and clinical observations have demonstrated that tumour cells can interfere with an immune response and that deficient activation of antitumour 
immunity, such as decreased expression of MHC class I and/or adhesion or accessory/costimulatory molecules and a lack of tumour antigen presentation may facilitate tumour progression (42). Activation of the CD40 pathway can increase antigen presentation, and enhance cytotoxic activity and cytokine secretion, thereby enhancing the host's antitumour immune effect (46).

\section{The profiles of agonistic antibodies targeting CD40 for cancer therapy}

As a target for cancer treatment, CD40 can be activated by three approaches under clinical research (47): Recombinant human CD40L, adenovirus vector-expressed CD40L and agonistic anti-CD40 mAbs.

Due to its action on both the immune system and tumour cells, agonistic anti-CD40 antibodies have been studied as novel cancer immunotherapy targets, demonstrating potent antitumour immune responses in animal models and cancer patients $(13,48-50)$. Each of the agonistic anti-CD40 mAbs has unique characteristics, including unique binding affinities to CD40, antibody isotypes, Fc modifications and agonistic effects (Table I). However, there is no consensus on which agonist is best for cancer therapy at present (51).

It is worth mentioning that the generation mechanism by which each of these antibodies generates agonism is not exactly the same. IgG1 Fc domain engineering was employed for APX005M based on the finding in a murine model that the potency of a CD40 agonist can be enhanced by increased binding affinity to Fc $\gamma \mathrm{RIIB}(52,53)$. In contrast, agonism of an $\mathrm{IgG} 2 \mathrm{mAb}$, such as CP-870,893, is believed to be provided by its unique hinge conformation $(54,55)$. A recent study demonstrated that hinge rigidity and selective $\mathrm{Fc} \gamma \mathrm{R}$ binding affinity are both critical in regulating antibody agonistic function (56). In addition, other research has shown that the binding site is important in determining CD40 mAb agonistic activities, as membrane CRD1-binding displays stronger agonistic activities when the binding site is distal to the membrane than when it is proximal (57), and this relationship between binding epitope specificity and agonistic activity varies in TNFRs and needs to be resolved on a case-by-case basis (58).

\section{Clinical trials of anti-CD40 mAbs for treating the malignancies}

To date, a variety of agonistic anti-CD40 mAbs are currently under investigation in clinical trials, as monotherapies or in combination with other agents $(51,59-65)$. All these agonistic anti-CD40 mAbs are in the early developmental stage (Table II).

CP-870,893. CP-870,893 (now licensed to Roche Diagnostics under the names RO7009789 or Selicrelumab) is a fully humanized monoclonal IgG2 antibody that binds CD40 with a very high affinity $\left(\mathrm{K}_{\mathrm{d}}\right.$ of $\left.0.4 \mathrm{nmol} / \mathrm{l}\right)(66,67) . \mathrm{CP}-870,893$ has been shown in preclinical studies to be a strong agonist of CD40 without eliciting antibody-dependent cell-mediated cytotoxicity (ADCC), a mechanism through which an antibody induces target lysis by activating host leukocytic effector cells, or complement dependent cytotoxicity, a cascade of complement-related reactions leading to target lysis $(67,68)$.

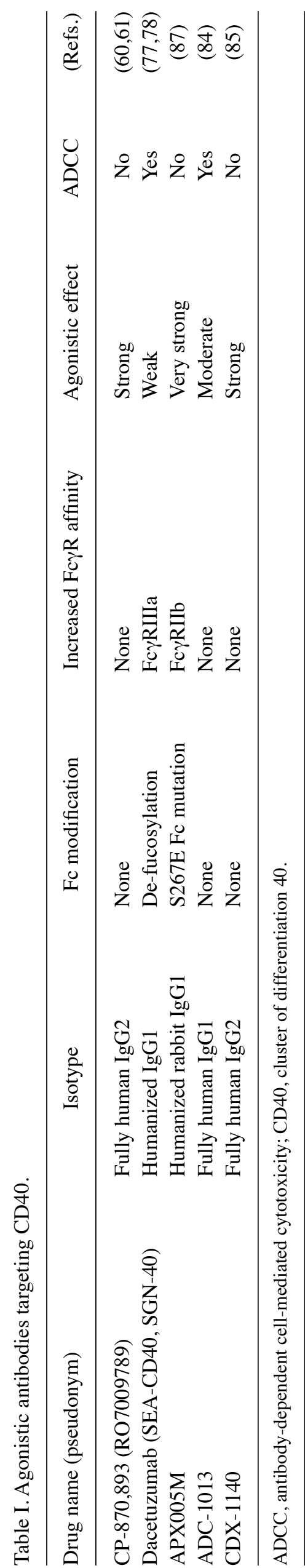




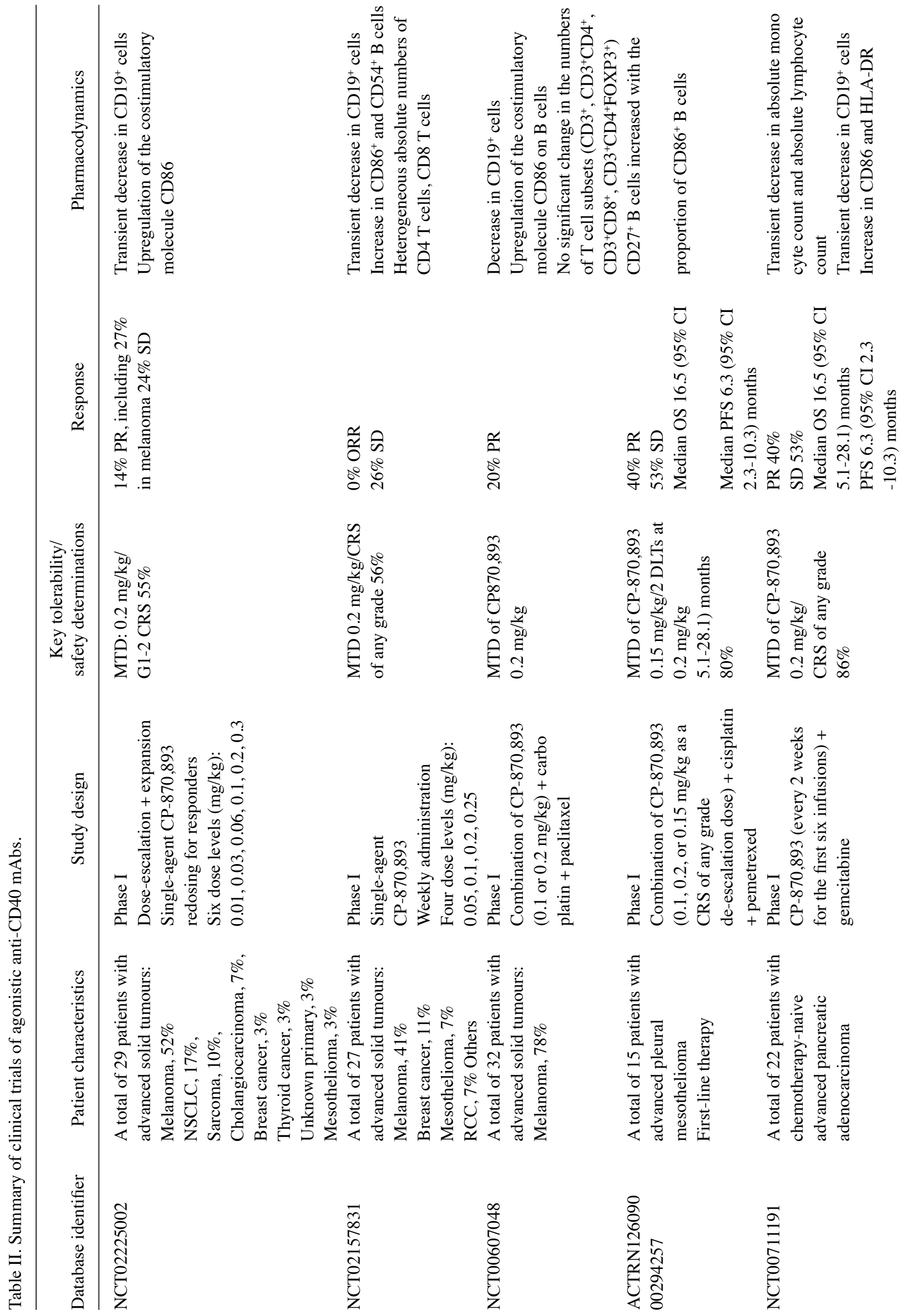




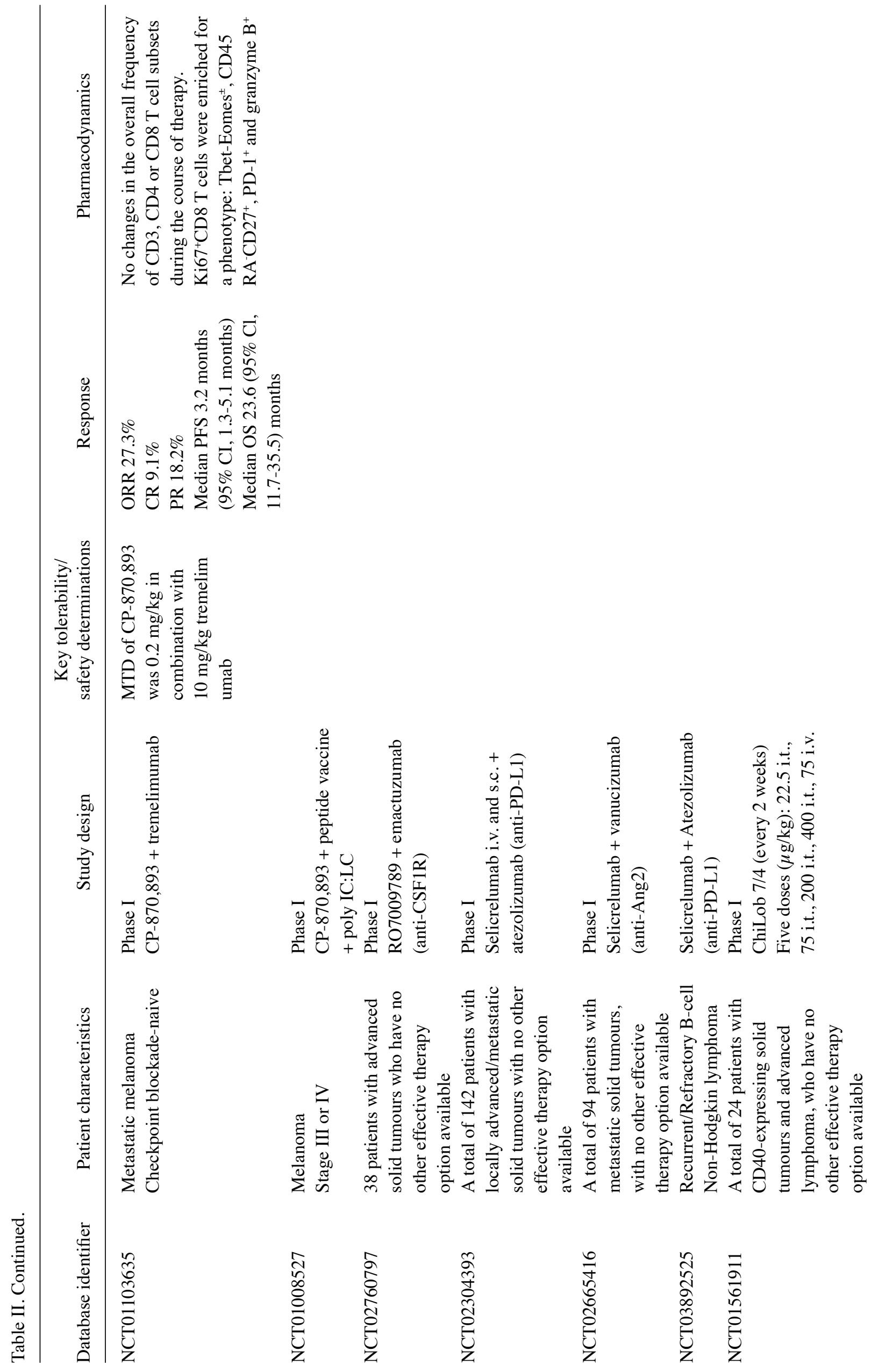




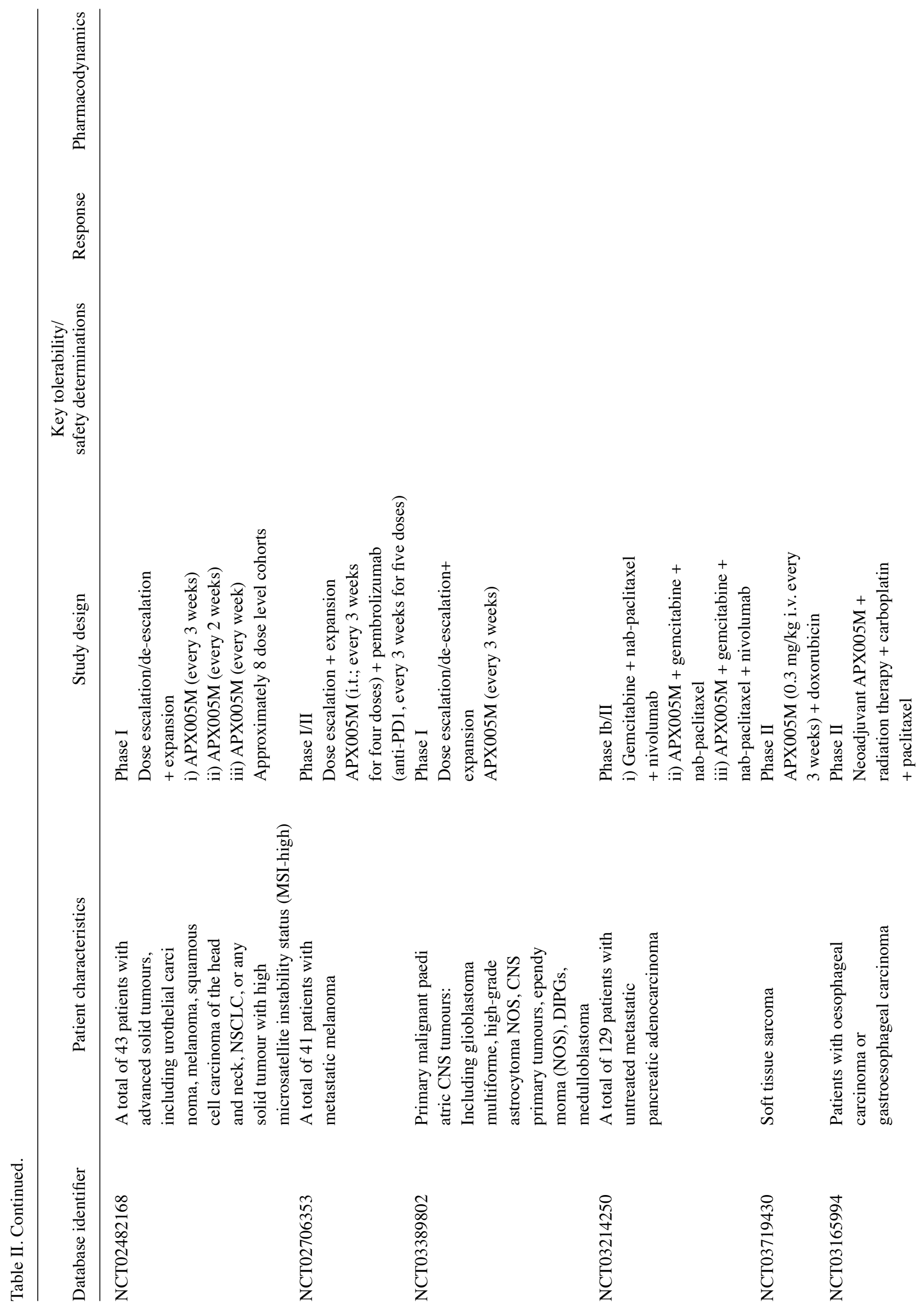




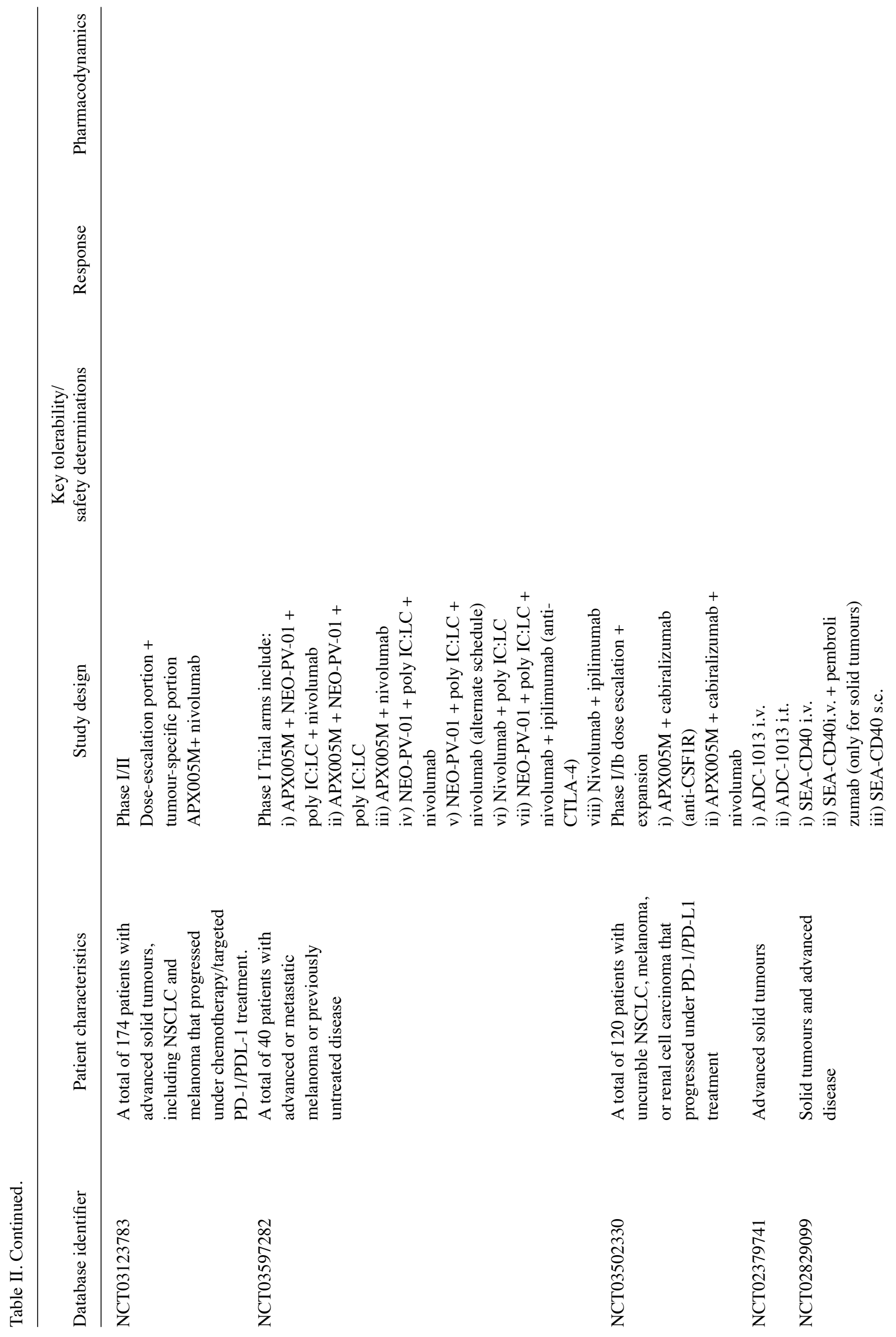




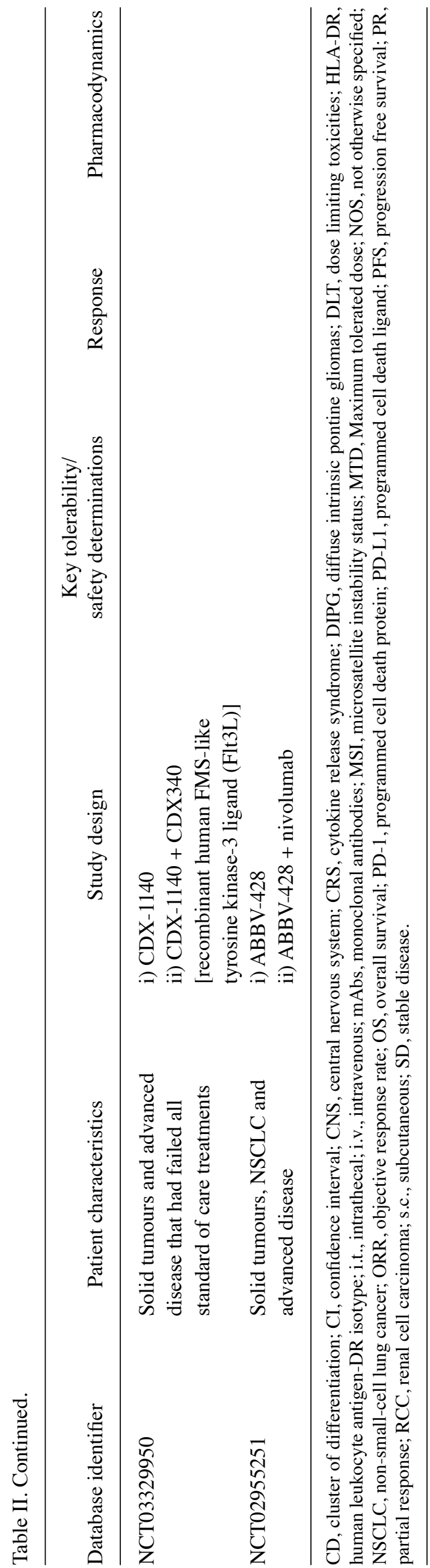

CP-870,893 was administered to 29 patients with advanced solid malignancies as a monotherapy in the first-in-human study (66). A total of six dose levels were investigated ranging from 0.01 to $0.3 \mathrm{mg} / \mathrm{kg}$. Dose-limiting toxicities (DLTs) in this trial were venous thromboembolism (one patient in the $0.3 \mathrm{mg} / \mathrm{kg}$ group), grade 3 headache (one patient in $0.3 \mathrm{mg} / \mathrm{kg}$ group), and grade 3 transient elevations in serum transaminases (one patient in the $0.2 \mathrm{mg} / \mathrm{kg}$ group), and $0.2 \mathrm{mg} / \mathrm{kg}$, was declared as the maximum-tolerated dose (MTD) (66). CP-870,893 was well tolerated and exhibited promising antitumour activity, especially in patients with melanoma. A partial response (PR) was achieved in four patients with advanced malignant melanoma as the best response, and one patient continued to respond for $>14$ months (66). Pharmacodynamically, CP-870,893 could induce a rapid and temporary decrease in peripheral $\mathrm{CD} 19^{+} \mathrm{B}$ cells and an upregulation of CD86 expression on APCs (66).

According to the clinical pharmacodynamic characteristics of CP-879,893, a weekly dosing schedule was designed for another phase I trial, which was conducted in 27 patients with multiple advanced solid tumours. The MTD of $0.2 \mathrm{mg} / \mathrm{kg}$ weekly was administered, and patients showed a good tolerability of CP-879,893. In contrast to the results of the single-dose study, $50 \%$ of patients had a significant decrease in $\mathrm{CD} 4^{+}$and $\mathrm{CD} 8^{+} \mathrm{T}$ cells, suggesting that the frequent dosing of CP-870,893 led to immune hyperstimulation, which resulted in counterproductive peripheral $\mathrm{T}$ cell depletion. No patient in this trial achieved partial responses or complete responses, and $26 \%$ of patients achieved stable disease (SD). This outcome indicates that the dose interval of 1 week is too short for cancer therapy (69).

Data from multiple preclinical models indicates that immune activation can be synergistically enhanced by combination with other treatments, including chemotherapy, therapeutic tumour vaccines, agitation of Toll-like receptors, cytokine therapy and blockades of immune checkpoint inhibitors (70-74). Thus, several studies were conducted to investigate the combined treatment of CP-870,893 with other agents. To date, there are three studies investigating the combination of CP-870,893 with chemotherapy in malignancy.

One dose-escalation study investigated CP-870,893 combined with carboplatin and paclitaxel in the treatment of advanced solid tumours (60). A total of 32 patients were enrolled in this trial, of whom 25 patients had metastatic melanoma. The MTD of CP-870,893 was established at $0.2 \mathrm{mg} / \mathrm{kg}$ every 3 weeks, as two DLTs were observed at this dose level (grade 3 cytokine release syndrome and transient ischaemic attack). This combination therapy was considered safe in patients with advanced solid tumours. However, PRs were observed in six out of 30 evaluable subjects (20\%) as the best response, and thus the study failed to demonstrate an obvious superior efficacy of the combination treatment over chemotherapy (60).

Another phase Ib study showed that CP-870,890 combined with cisplatin/pemetrexed at a dose of $0.15 \mathrm{mg} / \mathrm{kg}$ every 3 weeks was safe and tolerable in 15 patients with malignant mesothelioma (61). The efficacy results of this trial included six instances of PR (40\%) and nine instances of SD (53\%), which were similar to the results achieved with chemotherapy alone. 
The third study was conducted in 22 patients who had chemotherapy-naive advanced pancreatic ductal adenocarcinoma (PDA). The combination of a $0.2 \mathrm{mg} / \mathrm{kg}$ dose of CP-870,893 every 3 weeks and standard-of-care gemcitabine was well tolerated in the subjects. The objective response rate (ORR) was $19 \%$, the progression-free survival (PFS) was 5.2 months, and median overall survival was 8.4 months (60). With FDG-PET/CT imaging guidance, the authors found that some lesions responded and others failed to respond during therapy, suggesting that treatment responses to this therapy were heterogeneous (59).

Further studies investigated CP-870,893 combined with other immunomodulators. One study investigated CP-870,893 in combination with tremelimumab, an anti-cytotoxic T lymphocyte-associated protein 4 (CTLA4) mAb, for treating patients with metastatic melanoma. There was no increase in toxicity with the combination treatment compared with the single agents. Moreover, a promising efficacy was observed with an ORR of $27.3 \%$ and two complete responses (CRs) in this trial (75). By comparison, tremelimumab monotherapy in the treatment of advanced melanoma led to an ORR of $10.7 \%$ in a phase III study (76).

There are several ongoing early-phase trials to further investigate the potential of combination therapies of CP-870,893 and other biological agents. One study was designed to assess emactuzumab, a monoclonal antibody targeting colony-stimulating factor 1 receptor (CSF1R), administered in combination with CP-870,893 to participants with locally advanced or metastatic solid tumours (clinical trial identifier: NCT02760797). Another two trials investigated CP-870,893 combined with vanucizumab, a bispecific antibody targeting angiopoietin 2 and vascular endothelial growth factor (VEGF), or bevacizumab, an anti-VEGF $\mathrm{mAb}$, and in combination with atezolizumab (an anti-PD-L1 mAb) in metastatic solid tumours (clinical trial identifiers: NCT02665416 and NCT02304393, respectively). A clinical study investigating neoadjuvant application of CP-870,893 combined with gemcitabine in resectable PDA is now ongoing (clinical trial identifier: NCT01456585).

Dacetuzumab. Dacetuzumab, also named SEA-40 or SGN-40, is a humanized CD40 targeted IgG1 mAb developed by Seattle Genetics, Inc. As a weak agonist $\left(\mathrm{K}_{\mathrm{d}} \approx 1 \mathrm{nmol} / \mathrm{l}\right)$, dacetuzumab does not block the CD40/CD40L interaction in vitro (77). Dacetuzumab was engineered in an afucosylated IgG1 format to improve the ADCC potential (78). Preclinical results have demonstrated that dacetuzumab induces apoptosis of non-Hodgkin's lymphoma cells in vivo by ADCC, antibody-dependent cellular phagocytosis (ADCP), and direct apoptotic signalling $(77,79)$.

The first in-human study of dacetuzumab was conducted in 44 patients with recurrent or refractory advanced multiple myeloma. The patients tolerated dacetuzumab well. The MTD was established at $12 \mathrm{mg} / \mathrm{kg} /$ week. No patient achieved CR or $\mathrm{PR}$, and the best clinical response observed in this trial was SD in nine patients (62).

Another phase I trial of dacetuzumab was conducted in 50 patients with the relapsed/refractory Non-Hodgkin Lymphoma subtype. This trial used an intrapatient dose-escalation schedule with a maximum weekly dose of $8 \mathrm{mg} / \mathrm{kg}$ in five cohorts. In terms of safety, dacetuzumab was generally well tolerated with extended therapy in this trial. The ORR was $12 \%$, with one patient with relapsed DLBCL achieving a durable CR for $>1$ year (80). Next, a phase II study was conducted to assess the efficacy and safety of dacetuzumab in 46 patients with relapsed DLBCL. Subjects in this trial received up to 12 cycles of dacetuzumab; the ORR was $9 \%$, and the disease control rate was $37 \%$, which suggests modest activity of dacetuzumab as monotherapy in unselected patients with relapsed DLBCL (64).

A synergistic effect was observed when dacetuzumab in combination with other agents such as rituximab, was administered in vivo, which provided a rationale for combination therapy with dacetuzumab. In a pilot phase Ib study, a regimen of dacetuzumab combined with rituximab and gemcitabine was investigated in patients with relapsed or refractory DLBCLs. The complete response rate in this study was $20 \%$, and the partial response rate was $27 \%$ (81). Due to this efficacy outcome, a randomized, double-blind, placebo-controlled, phase IIb clinical trial was conducted to investigate dacetuzumab or placebo in combination with rituximab plus ifosfamide, carboplatin, and etoposide chemotherapy in 151 patients with relapsed or refractory DLBCL. The futility analysis failed to demonstrate a superior CR rate of the dacetuzumab group $(36 \%$ for the dacetuzumab treatment group compared with $42 \%$ for the placebo treatment group), which ended study enrolment (63).

ChiLob 7/4. ChiLob 7/4 (University of Southampton, UK) is a chimeric agonistic anti-CD40 IgG1 antibody. Preclinical studies showed that ChiLob $7 / 4$ has the ability to inhibit the growth of various CD40-expressing human malignant lymphoma and epithelial cell lines (82). A phase I study was conducted in 28 CD40-positive patients with solid tumours or lymphomas. The study showed that ChiLob 7/4 was well tolerated. The MTD was established at $200 \mathrm{mg}$ weekly for 4 doses, and patients with stable disease were observed (83). CD40 staining intensity was not associated with disease stabilization.

Several other agonistic CD40 mAbs are currently being investigated in clinical trials. ADC-1013, sponsored by Alligator Bioscience, is a fully human agonistic anti-CD40 IgG1 mAb with high affinity for CD40 $\left(\mathrm{K}_{\mathrm{d}}=0.01 \mathrm{nM}\right)$. A preclinical study demonstrated significant antitumour responses in bladder cancer models (84). A dose-escalation phase I trial is recruiting subjects with advanced solid tumours (clinical trial identifier: NCT02829099). A total of 23 patients received ADC-1013 treatment intravenously (dosing at $75 \mu \mathrm{g} / \mathrm{kg}$ ) or intratumourally (dosing from $22.5 \mu \mathrm{g} / \mathrm{kg}$ up to $400 \mu \mathrm{g} / \mathrm{kg}$ ). This study demonstrated good tolerability of intratumoural administration of ADC-1013 at a clinically relevant dose. Pharmacodynamic responses, such as a decrease in B lymphocyte levels in peripheral blood and overexpression of CD86, a cell surface activation marker, on remaining B lymphocytes, were observed (65).

\section{Other agonistic CD40 antibodies}

CDX-1140, developed by Celldex Therapeutics, Inc., is a human IgG2 antibody that stimulates CD40 signalling without the requirement for cross-linking or Fc receptor interactions (85). 
This drug is currently being investigated in a phase I clinical trial.

ABBV-927 (AbbVie, Inc.) is an anti-CD40/anti-mesothelin bispecific antibody that is being tested in phase I trials for the treatment of advanced solid tumours, including non-small cell lung cancer, squamous cell carcinoma of the head and neck, cutaneous malignant melanoma, and pancreatic adenocarcinoma, as monotherapy or in combination with other immunotherapies (anti-PD-1 and anti-OX40 antibodies) (86). The estimated primary completion date is 2023 .

APX005M, developed by Apexigen, is a humanized $\mathrm{mAb}$ IgG1/k against CD40 (87). A preclinical study has demonstrated that APX005M binds to CD40 at the CD40L binding domain with a high affinity in mice $\left(\mathrm{K}_{\mathrm{d}}=0.12 \mathrm{nM}\right)$ and monkeys $\left(\mathrm{K}_{\mathrm{d}}=0.37 \mathrm{nM}\right)$. The first-in-human phase I study for dose determination was conducted in patients with solid tumours (clinical trial identifier: NCT02482168) in 2015. The trial was completed at the end of 2018 without the results being reported. In 2017, three phase Ib/II studies and one phase II study were launched to investigate the safety and potential efficacy of APX005M combined with immune checkpoint inhibitors or chemotherapy in a variety of solid tumours, including APX005M combined with pembrolizumab for treating metastatic melanoma (clinical trial identifier: NCT02706353), a combination of APX005M and nivolumab in the treatment of solid tumours (clinical trial identifier: NCT03123783), APX005M in combination with chemotherapy with or without nivolumab in the treatment of metastasized pancreatic adenocarcinoma (clinical trial identifier: NCT03214250), and APX005M in combination with concurrent chemoradiation for resectable oesophageal/gastro-oesophageal carcinoma (clinical trial identifier: NCT03165994). In 2018, three phase I studies were launched. One study (clinical trial identifier: NCT03389802) has investigated the potential to overcome resistance to PD-1/PD-L1 blockade immunotherapy by the combination of APX005M with cabiralizumab, an anti-CSF1R antagonist, with and without nivolumab in several solid tumours. Another study (clinical trial identifier: NCT03502330) investigated the therapeutic potential of APX005M for treating paediatric CNS tumours. In addition, an innovative study (clinical trial identifier: NCT03597282) investigated the potential synergistic effect of APX005M with a vaccine (NEO-PV-01) in patients with advanced melanoma. In 2019, a phase II randomized multicentre trial was initiated for neoadjuvant therapy with or without APX005M in patients with locally advanced rectal adenocarcinoma. These trials are still ongoing at time of writing.

\section{Safety and clinical tolerability of anti-CD40 agonistic antibodies}

At present, most agonistic anti-CD40 antibodies have been demonstrated to be well tolerated both as single agents and in combination in the treatment of solid tumours and haematological malignancies $(47,50)$. Nevertheless, due to most agonistic anti-CD40 antibodies being in the early development stage, the safety information of these agents has not been fully investigated. The most common adverse events associated with CP-870,893, a fully humanized $\operatorname{IgG} 2$ antibody and a strong agonist, was transient grade 1 to grade 2 cytokine release syndrome (CRS). This syndrome, which occurs within minutes to hours after infusion, is characterized by a variety of combinations of chills, rigors, rash, nausea, fever, vomiting, muscle aches and back pain. In a human phase I study of CP-870,893, the CRS occurring in $55 \%$ of patients was considered to not be an anaphylactic or allergic reaction by the authors, as normal serum tryptase levels were observed in the subjects (66). There was an association of CP-870,890 with acute elevations in TNF- $\alpha$ and IL-6 in serum. In most cases, this syndrome can be resolved by treatment with doxylamine within $24 \mathrm{~h}$. Similar to CP-870,890, dacetuzumab, a weakly-agonistic humanized IgG1 antibody, showed a high overall incidence of CRS within one day of infusion (41\%) in the first-in-human trial, but the agents were generally tolerated well.

Another major safety issue of CP-870,893 is dose-related haematological toxicities, such as a decrease in peripheral lymphocytes, monocytes and platelets. Grade 3-4 lymphopenia and thrombocytopenia were observed in a clinical trial of CP-870,893. Grade 3 anaemia, neutropenia, and thrombocytopenia were observed in a human study of dacetuzumab. Weekly dosing of CP-870,893 may cause long-lasting lymphocytopenia.

Transient elevations in D-dimer levels and two pulmonary embolism cases (grade 4 thrombosis: Of which, one was from the single-dose schedule and one was from the weekly dose schedule) were observed in two phase I clinical trials of CP-870,893.

Aaspartate aminotransferase, alanine aminotransferase and total bilirubin were transiently increased after both CP-870,893 and dacetuzumab infusion, which suggests hepatoxicity of both agents. A study of the weekly dose schedule of CP-870,893 showed that liver enzyme abnormalities returned to baseline in most patients at the time of the next infusion. A human study of dacetuzumab showed that elevations in hepatic transaminases were asymptomatic and not associated with marked changes in bilirubin.

\section{Conclusion and outlook}

APC dysfunction remains a rate-limiting biological issue in many cancer environments. Targeting CD40 with agonists to enhance APC function and indirectly regulate host immune cells by recruiting innate immune effectors via ADCC/ADCP is considered a promising method to treat cancers. To date, early clinical trials have shown that anti-CD40 antibodies have limited clinical activity and no severe immune-related autoimmune-like toxicities, either as monotherapies or in combination with other treatments. Thus, combination strategies targeting of CD40 for cancer therapy require further investigation in clinical trials with careful designs.

\section{Acknowledgements}

Not applicable.

\section{Funding}

No funding was received.

\section{Availability of data and materials}

Not applicable. 


\section{Authors' contributions}

DKL and WW searched and collected relevant literature sources. DKL drafted the initial manuscript. WW reviewed and edited the manuscript. Both authors read and approved the manuscript and agree to be responsible for the accuracy of the information and the relevant sources.

\section{Ethics approval and consent to participate}

Not applicable.

\section{Patient consent for publication}

Not applicable.

\section{Competing interests}

The authors declare that they have no competing interests.

\section{References}

1. Clark EA and Ledbetter JA: Amplification of the immune response by agonistic antibodies. Immunol Today 7: 267-270, 1986.

2. Smith CA, Farrah T and Goodwin RG: The TNF receptor superfamily of cellular and viral proteins: Activation, costimulation, and death. Cell 76: 959-962, 1994.

3. Gauchat JF, Aubry JP, Mazzei G, Life P, Jomotte T, Elson G and Bonnefoy JY: Human CD40-ligand: Molecular cloning, cellular distribution and regulation of expression by factors controlling IgE production. FEBS Lett 315: 259-266, 1993.

4. Galy A and Spits H: CD40 is functionally expressed on human thymic epithelial cells. J Immunol 149: 775-782, 1992.

5. Yellin MJ, Brett J, Baum D, Matsushima A, Szabolcs M, Stern D and Chess L: Functional interactions of T cells with endothelial cells: The role of CD40L-CD40-mediated signals. J Exp Med 182: 1857-1864, 1995.

6. Costello RT, Gastaut JA and Olive D: What is the real role of CD40 in cancer immunotherapy? Immunol Today 20: 488-493, 1999.

7. Ziebold JL, Hixon J, Boyd A and Murphy WJ: Differential effects of CD40 stimulation on normal and neoplastic cell growth. Arch Immunol Ther Exp (Warsz) 48: 225-233, 2000.

8. Graf D, Müller S, Korthäuer U, van Kooten C, Weise C and Kroczek RA: A soluble form of TRAP (CD40 ligand) is rapidly released after $\mathrm{T}$ cell activation. Eur J Immunol 25: 1749-1754, 1995.

9. André P, Prasad KS, Denis CV, He M, Papalia JM, Hynes RO, Phillips DR and Wagner DD: CD40L stabilizes arterial thrombi by a beta3 integrin-dependent mechanism. Nat Med 8: 247-252, 2002.

10. Eliopoulos AG and Young LS: The role of the CD40 pathway in the pathogenesis and treatment of cancer. Curr Opin Pharmacol 4 360-367, 2004

11. Hafeez U, Gan HK and Scott AM: Monoclonal antibodies as immunomodulatory therapy against cancer and autoimmune diseases. Curr Opin Pharmacol 41: 114-121, 2018.

12. Funakoshi S, Longo DL, Beckwith M, Conley DK, Tsarfaty G, Tsarfaty I, Armitage RJ, Fanslow WC, Spriggs MK and Murphy WJ: Inhibition of human B-Cell lymphoma growth by CD40 stimulation. Blood 83: 2787-2794, 1994.

13. Tutt AL, O'Brien L, Hussain A, Crowther GR, French RR and Glennie MJ: T cell immunity to lymphoma following treatment with anti-CD40 monoclonal antibody. J Immunol 168 : 2720-2728, 2002.

14. Hellstrom I and Hellstrom KE: Monoclonal antibodies for cancer therapy. In: Schwab M (ed.) Encyclopedia of Cancer. Springer Berlin, Heidelberg, Germany, 2014.

15. Pellat-Deceunynck C, Amiot M, Robillard N, Wijdenes J and Bataille R: CD11a-CD18 and CD102 interactions mediate human myeloma cell growth arrest induced by CD40 stimulation. Cancer Res 56: 1909-1916, 1996.
16. Eliopoulos AG, Davies C, Knox PG, Gallagher NJ, Afford SC, Adams DH and Young LS: CD40 induces apoptosis in carcinoma cells through activation of cytotoxic ligands of the tumor necrosis factor superfamily. Mol Cell Biol 20: 5503-5515, 2000.

17. Park CI, Hirono I, Hwang JY and Aoki T: Characterization and expression of a CD40 homolog gene in Japanese flounder Paralichthys olivaceus. Immunogenetics 57: 682-689, 2005.

18. McWhirter SM, Pullen SS, Holton JM, Crute JJ, Kehry MR and Alber T: Crystallographic analysis of CD40 recognition and signaling by human TRAF2. Proc Natl Acad Sci USA 96: 8408-8413, 1999.

19. Berberich I, Shu GL and Clark EA: Cross-linking CD40 on B cells rapidly activates nuclear factor-kappa B. J Immunol 153: 4357-4366, 1994.

20. Berberich I, Shu G, Siebelt F, Woodgett JR, Kyriakis JM and Clark EA: Cross-linking CD40 on B cells preferentially induces stress-activated protein kinases rather than mitogen-activated protein kinases. EMBO J 15: 92-101, 1996.

21. Ren CL, Morio T, Fu SM and Geha RS: Signal transduction via CD40 involves activation of lyn kinase and phosphatidylinositol-3-kinase, and phosphorylation of phospholipase C gamma 2. J Exp Med 179: 673-680, 1994.

22. Li YY, Baccam M, Waters SB, Pessin JE, Bishop GA and Koretzky GA: CD40 ligation results in protein kinase $\mathrm{C}$-independent activation of ERK and JNK in resting murine splenic B cells. J Immunol 157: 1440-1447, 1996.

23. Notarangelo LD, Peitsch MC, Abrahamsen TG, Bachelot C, Bordigoni P, Cant AJ, Chapel H, Clementi M, Deacock S, de Saint Basile G, et al: CD40lbase: A database of CD40L gene mutations causing X-linked hyper-IgM syndrome. Immunol Today 17: 511-516, 1996.

24. Villa A, Notarangelo LD, Di Santo JP, Macchi PP, Strina D, Frattini A, Lucchini F, Patrosso CM, Giliani S, Mantuano E, et al: Organization of the human CD40L gene: Implications for molecular defects in X chromosome-linked hyper-IgM syndrome and prenatal diagnosis. Proc Natl Acad Sci USA 91: 2110-2114, 1994.

25. Schönbeck U and Libby P: The CD40/CD154 receptor/ligand dyad. Cell Mol Life Sci 58: 4-43, 2001.

26. Grewal IS and Flavell RA: CD40 and CD154 in cell-mediated immunity. Annu Rev Immunol 16: 111-135, 1998.

27. Tong AW and Stone MJ: Prospects for CD40-directed experimental therapy of human cancer. Cancer Gene Ther 10: 1-13, 2003.

28. Cella M, Scheidegger D, Palmer-Lehmann K, Lane P, Lanzavecchia A and Alber G: Ligation of CD40 on dendritic cells triggers production of high levels of interleukin-12 and enhances T cell stimulatory capacity: T-T help via APC activation. J Exp Med 184: 747-752, 1996.

29. Lum HD, Buhtoiarov IN, Schmidt BE, Berke G, Paulnock DM, Sondel PM and Rakhmilevich AL: In vivo CD40 ligation can induce T-cell-independent antitumor effects that involve macrophages. J Leukoc Biol 79: 1181-1192, 2006.

30. Arango Duque G and Descoteaux A: Macrophage cytokines: Involvement in immunity and infectious diseases. Front Immunol 5: 491, 2014

31. Stow JL, Low PC, Offenhäuser C and Sangermani D: Cytokine secretion in macrophages and other cells: Pathways and mediators. Immunobiology 214: 601-612, 2009.

32. van Kooten C and Banchereau J: Functions of CD40 on B cells, dendritic cells and other cells. Curr Opin Immunol 9: 330-337, 1997.

33. Arpin C, Déchanet J, Van Kooten C, Merville P, Grouard G, Brière F, Banchereau J and Liu YJ: Generation of memory B cells and plasma cells in vitro. Science 268: 720-722, 1995.

34. Huse K, Wogsland CE, Polikowsky HG, Diggins KE, Smeland EB, Myklebust JH and Irish JM: Human germinal center B cells differ from naive and memory B cells in CD40 expression and CD40L-induced signaling response. Cytometry A 95: 442-449, 2019.

35. Hill A and Chapel H: X-linked immunodeficiency. The fruits of cooperation. Nature 361: 494, 1993.

36. Vonderheide RH: Prospect of targeting the CD40 pathway for cancer therapy. Clin Cancer Res 13: 1083-1088, 2007.

37. Planken EV, Dijkstra NH, Bakkus M, Willemze $\mathrm{R}$ and Kluin-Nelemans JC: Proliferation of precursor B-lineage acute lymphoblastic leukaemia by activating the CD40 antigen. $\mathrm{Br}$ J Haematol 95: 319-326, 1996.

38. Murphy WJ, Funakoshi S, Fanslow WC, Rager HC, Taub DD and Longo DL: CD40 stimulation promotes human secondary immunoglobulin responses in HuPBL-SCID chimeras. Clin Immunol 90: 22-27, 1999. 
39. Voorzanger-Rousselot N, Favrot M and Blay JY: Resistance to cytotoxic chemotherapy induced by CD40 ligand in lymphoma cells. Blood 92: 3381-3387, 1998.

40. Castillo R, Mascarenhas J, Telford W, Chadburn A, Friedman SM and Schattner EJ: Proliferative response of mantle cell lymphoma cells stimulated by CD40 ligation and IL-4. Leukemia 14: 292-298, 2000

41. Kusam S, Munugalavadla V, Sawant D and Dent A: BCL6 cooperates with CD40 stimulation and loss of p53 function to rapidly transform primary B cells. Int J Cancer 125: 977-981, 2009.

42. Garrone P, Neidhardt EM, Garcia E, Galibert L, van Kooten C and Banchereau J: Fas ligation induces apoptosis of CD40-activated human B lymphocytes. J Exp Med 182: 1265-1273, 1995.

43. Schattner EJ, Mascarenhas J, Bishop J, Yoo DH and Friedman SM: $\mathrm{CD}^{+} \mathrm{T}$-cell induction of Fas-mediated apoptosis in Burkitt's lymphoma B cells. Blood 88: 1375-1382, 1996.

44. Lee HH, Dadgostar H, Cheng Q, Shu J and Cheng G: NF-kappaB-mediated up-regulation of $\mathrm{Bcl}-\mathrm{x}$ and $\mathrm{Bfl}-1 / \mathrm{A} 1$ is required for CD40 survival signaling in B lymphocytes. Proc Natl Acad Sci USA 96: 9136-9141, 1999.

45. Chu P, Deforce D, Pedersen IM, Kim Y, Kitada S, Reed JC and Kipps TJ: Latent sensitivity to Fas-mediated apoptosis after CD40 ligation may explain activity of CD154 gene therapy in chronic lymphocytic leukemia. Proc Natl Acad Sci USA 99: 3854-3859, 2002.

46. Elgueta R, Benson MJ, de Vries VC, Wasiuk A, Guo Y and Noelle RJ: Molecular mechanism and function of CD40/CD40L engagement in the immune system. Immunol Rev 229: 152-172, 2009.

47. Piechutta $\mathrm{M}$ and Berghoff AS: New emerging targets in cancer immunotherapy: The role of Cluster of Differentiation 40 (CD40/TNFR5). ESMO Open 4: e000510, 2019.

48. French RR, Chan HC, Tutt AL and Glennie MJ: CD40 antibody evokes a cytotoxic T-cell response that eradicates lymphoma and bypasses T-cell help. Nature medicine 5: 548-553, 1999.

49. Todryk SM, Tutt AL, Green MH, Smallwood JA, Halanek N, Dalgleish AG and Glennie MJ: CD40 ligation for immunotherapy of solid tumours. J Immunol Methods 248: 139-147, 2001.

50. Remer M, White A, Glennie M, Al-Shamkhani A and Johnson P: The use of anti-CD40 mAb in cancer. Curr Top Microbiol Immunol 405: 165-207, 2017.

51. Vonderheide RH: CD40 agonist antibodies in cancer immunotherapy. Annu Rev Med 71: 47-58, 2020.

52. White AL, Chan HT, Roghanian A, French RR, Mockridge CI Tutt AL, Dixon SV, Ajona D, Verbeek JS, Al-Shamkhani A, et al: Interaction with Fc $\gamma$ RIIB is critical for the agonistic activity of anti-CD40 monoclonal antibody. J Immunol 187: 1754-1763, 2011.

53. Johnson M, Fakih M, Bendell J, Bajor D, Cristea M, Tremblay $\mathrm{T}$, Trifan $\mathrm{O}$ and Vonderheide R: First in human study with the CD40 agonistic monoclonal antibody APX005M in subjects with solid tumors. J Immuno Ther Cancer 5: 89, 2017.

54. Richman LP and Vonderheide RH: Role of crosslinking for agonistic CD40 monoclonal antibodies as immune therapy of cancer. Cancer Immunol Res 2: 19-26, 2014.

55. White AL, Chan HC, French RR, Willoughby J, Mockridge CI Roghanian A, Penfold CA, Booth SG, Dodhy A, Polak ME, et al Conformation of the human immunoglobulin G2 hinge imparts superagonistic properties to immunostimulatory anticancer antibodies. Cancer Cell 27: 138-148, 2015.

56. Liu X, Zhao Y, Shi H, Zhang Y, Yin X, Liu M, Zhang H, He Y, $\mathrm{Lu}$ B, Jin T and Li F: Human immunoglobulin $\mathrm{G}$ hinge regulates agonistic anti-CD40 immunostimulatory and antitumour activities through biophysical flexibility. Nat Commun 10: 4206, 2019

57. Yu X, Chan HC, Orr CM, Dadas O, Booth SG, Dahal LN, Penfold CA, O'Brien L, Mockridge CI, French RR, et al: Complex interplay between epitope specificity and isotype dictates the biological activity of anti-human CD40 antibodies. Cancer Cell 33: 664-675. e664, 2018.

58. Zhang P, Tu GH, Wei J, Santiago P, Larrabee LR, Liao-Chan S, Mistry T, Chu ML, Sai T, Lindquist K, et al: Ligand-blocking and membrane-proximal domain targeting anti-OX40 antibodies mediate potent $\mathrm{T}$ cell-stimulatory and anti-tumor activity. Cell Rep 27: 3117-3123. e3115, 2019.

59. Beatty GL, Torigian DA, Chiorean EG, Saboury B, Brothers A Alavi A, Troxel AB, Sun W, Teitelbaum UR, Vonderheide RH and O'Dwyer PJ: A phase I study of an agonist CD40 monoclonal antibody (CP-870,893) in combination with gemcitabine in patients with advanced pancreatic ductal adenocarcinoma. Clin Cancer Res 19: 6286-6295, 2013
60. Vonderheide RH, Burg JM, Mick R, Trosko JA, Li D, Shaik MN, Tolcher AW and Hamid O: Phase I study of the CD40 agonist antibody CP-870,893 combined with carboplatin and paclitaxel in patients with advanced solid tumors. Oncoimmunology 2: e23033, 2013

61. Nowak A, Cook A, McDonnell A, Millward MJ, Creaney J, Francis RJ, Hasani A, Segal A, Musk AW, Turlach BA, et al: A phase $1 \mathrm{~b}$ clinical trial of the CD40-activating antibody CP-870,893 in combination with cisplatin and pemetrexed in malignant pleural mesothelioma. Ann Oncol 26: 2483-2490, 2015.

62. Furman RR, Forero-Torres A, Shustov A and Drachman JG: A phase I study of dacetuzumab (SGN-40, a humanized anti-CD40 monoclonal antibody) in patients with chronic lymphocytic leukemia. Leuk Lymphoma 51: 228-235, 2010.

63. Fayad L, Ansell SM, Advani R, Coiffier B, Stuart R, Bartlett NL, Forero-Torres A, Kuliczkowski K, Belada D, Ng E and Drachman JG: Dacetuzumab plus rituximab, ifosfamide, carboplatin and etoposide as salvage therapy for patients with diffuse large B-cell lymphoma relapsing after rituximab, cyclophosphamide, doxorubicin, vincristine and prednisolone: A randomized, double-blind, placebo-controlled phase $2 \mathrm{~b}$ trial. Leuk Lymphoma 56: 2569-2578, 2015.

64. de Vos S, Forero-Torres A, Ansell SM, Kahl B, Cheson BD, Bartlett NL, Furman RR, Winter JN, Kaplan H, Timmerman J, et al: A phase II study of dacetuzumab (SGN-40) in patients with relapsed diffuse large B-cell lymphoma (DLBCL) and correlative analyses of patient-specific factors. J Hematol Oncol 7: 44, 2014.

65. Irenaeus SMM, Nielsen D, Ellmark P, Yachnin J, Deronic A Nilsson A, Norlén P, Veitonmäki N, Wennersten CS and Ullenhag GJ: First-in-human study with intratumoral administration of a CD40 agonistic antibody, ADC-1013, in advanced solid malignancies. Int J Cancer 145: 1189-1199, 2019.

66. Vonderheide RH, Flaherty KT, Khalil M, Stumacher MS Bajor DL, Hutnick NA, Sullivan P, Mahany JJ, Gallagher M, Kramer A, et al: Clinical activity and immune modulation in cancer patients treated with CP-870,893, a novel CD40 agonist monoclonal antibody. J Clin Oncol 25: 876-883, 2007.

67. Gladue RP, Paradis T, Cole SH, Donovan C, Nelson R, Alpert R, Gardner J, Natoli E, Elliott E, Shepard R and Bedian V: The CD40 agonist antibody CP-870,893 enhances dendritic cell and B-cell activity and promotes anti-tumor efficacy in SCID-hu mice. Cancer Immunol Immunother 60: 1009-1017, 2011

68. Kalbasi A, Fonsatti E, Natali PG, Altomonte M, Bertocci E, Cutaia O, Calabrò L, Chiou M, Tap W, Chmielowski B, et al: CD40 expression by human melanocytic lesions and melanoma cell lines and direct CD40 targeting with the therapeutic anti-CD40 antibody CP-870,893. J Immunother 33: 810-816, 2010.

69. Rüter J, Antonia SJ, Burris HA, Huhn RD and Vonderheide RH: Immune modulation with weekly dosing of an agonist CD40 antibody in a phase I study of patients with advanced solid tumors. Cancer Biol Ther 10: 983-993, 2010.

70. Ghamande S, Hylander BL, Oflazoglu E, Lele S, Fanslow W and Repasky EA: Recombinant CD40 ligand therapy has significant antitumor effects on CD40-positive ovarian tumor xenografts grown in SCID mice and demonstrates an augmented effect with cisplatin. Cancer Res 61: 7556-7562, 2001.

71. Ahonen CL, Doxsee CL, McGurran SM, Riter TR, Wade WF, Barth RJ, Vasilakos JP, Noelle RJ and Kedl RM: Combined TLR and CD40 triggering induces potent $\mathrm{CD}^{+} \mathrm{T}$ cell expansion with variable dependence on type I IFN. J Exp Med 199: 775-784, 2004.

72. Uno T, Takeda K, Kojima Y, Yoshizawa H, Akiba H, Mittler RS, Gejyo F, Okumura K, Yagita H and Smyth MJ: Eradication of established tumors in mice by a combination antibody-based therapy. Nat Med 12: 693, 2006.

73. Kirk AD, Harlan DM, Armstrong NN, Davis TA, Dong Y, Gray GS, Hong X, Thomas D, Fechner JH Jr and Knechtle SJ: CTLA4-Ig and anti-CD40 ligand prevent renal allograft rejection in primates. Proc Natl Acad Sci USA 94: 8789-8794, 1997.

74. Luheshi NM, Coates-Ulrichsen J, Harper J, Mullins S, Sulikowski MG, Martin P, Brown L, Lewis A, Davies G, Morrow $\mathrm{M}$ and Wilkinson RW: Transformation of the tumour microenvironment by a CD40 agonist antibody correlates with improved responses to PD-L1 blockade in a mouse orthotopic pancreatic tumour model. Oncotarget 7: 18508, 2016. 
75. Bajor DL, Mick R, Riese MJ, Huang AC, Sullivan B, Richman LP, Torigian DA, George SM, Stelekati E, Chen F, et al: Long-term outcomes of a phase I study of agonist CD40 antibody and CTLA-4 blockade in patients with metastatic melanoma. Oncoimmunology 7: e1468956, 2018.

76. Ribas A, Kefford R, Marshall MA, Punt CJ, Haanen JB, Marmol M, Garbe C, Gogas H, Schachter J, Linette G, et al: Phase III randomized clinical trial comparing tremelimumab with standard-of-care chemotherapy in patients with advanced melanoma. J Clin Oncol 31: 616-622, 2013.

77. Khubchandani S, Czuczman MS and Hernandez-Ilizaliturri FJ: Dacetuzumab, a humanized mAb against CD40 for the treatment of hematological malignancies. Curr Opin Investig Drugs 10 579-587, 2009

78. Law CL, Gordon KA, Collier J, Klussman K, McEarchern JA, Cerveny CG, Mixan BJ, Lee WP, Lin Z, Valdez P, et al: Preclinical antilymphoma activity of a humanized anti-CD40 monoclonal antibody, SGN-40. Cancer Res 65: 8331-8338, 2005.

79. Oflazoglu E, Stone IJ, Brown L, Gordon KA, van Rooijen N, Jonas M, Law CL, Grewal IS and Gerber HP: Macrophages and Fc-receptor interactions contribute to the antitumour activities of the anti-CD40 antibody SGN-40. Br J Cancer 100: 113-117, 2009.

80. Advani R, Forero-Torres A, Furman RR, Rosenblatt JD, Younes A, Ren H, Harrop K, Whiting N and Drachman JG: Phase I study of the humanized anti-CD40 monoclonal antibody dacetuzumab in refractory or recurrent non-Hodgkin's lymphoma. J Clin Oncol 27: 4371-4377, 2009.

81. Forero-Torres A, Bartlett N, Beaven A, Myint H, Nasta S, Northfelt DW, Whiting NC, Drachman JG, Lobuglio AF and Moskowitz CH: Pilot study of dacetuzumab in combination with rituximab and gemcitabine for relapsed or refractory diffuse large B-cell lymphoma. Leuk Lymphoma 54: 277-283, 2013.

82. Geldart TR, Harvey M, Carr N, Glennie M and Johnson P: Cancer immunotherapy with a chimeric anti-CD40 monoclonal antibody: Evidence of preclinical efficacy. J Clin Oncol 22: 2577-2577, 2004.

83. Johnson PW, Challis R, Chowdhury F, Chan C, Smith A, Steven N, Edwards C, Ashton-Key M, Hodges E, Tutt A, et al: Abstract LB-142: A trial of agonistic anti-CD40 antibody: Biological effects in a Cancer Research UK phase I study. Cancer Res 73, 2013.

84. Mangsbo SM, Broos S, Fletcher E, Veitonmäki N, Furebring C, Dahlén E, Norlén P, Lindstedt M, Tötterman TH and Ellmark P: The human agonistic CD40 antibody ADC-1013 eradicates bladder tumors and generates T-cell-dependent tumor immunity. Clin Cancer Res 21: 1115-1126, 2015.

85. Vitale LA, Thomas LJ, He LZ, O'Neill T, Widger J, Crocker A, Sundarapandiyan K, Storey JR, Forsberg EM, Weidlick J, et al: Development of CDX-1140, an agonist CD40 antibody for cancer immunotherapy. Cancer Immunol Immunother 68: 233-245, 2019.

86. Santuray RT, Johnson DE and Grandis JR: New therapies in head and neck cancer. Trends Cancer 4: 385-396, 2018.

87. Bjorck P, Filbert E, Zhang Y, Yang X and Trifan O: The CD40 agonistic monoclonal antibody APX005M has potent immune stimulatory capabilities. J Immunother Cancer 3: P198, 2015.

(i) $\Theta$ This work is licensed under a Creative Commons Attribution-NonCommercial-NoDerivatives 4.0 International (CC BY-NC-ND 4.0) License. 